\begin{abstract}
Iranica
Abstracta Iranica Revue bibliographique pour le domaine irano-aryen

Volume 34-35-36 | 2017

Comptes rendus des publications de 2011-2013
\end{abstract}

\title{
Florence Jullien (ed.). Eastern Christianity: a Crossroads of Cultures
}

\section{Christelle Jullien}

\section{(2) OpenEdition}

1 Journals

\section{Édition électronique}

URL : http://journals.openedition.org/abstractairanica/41275

DOI : 10.4000/abstractairanica.41275

ISSN : 1961-960X

Éditeur :

CNRS (UMR 7528 Mondes iraniens et indiens), Éditions de l'IFRI

\section{Référence électronique}

Christelle Jullien, «Florence Jullien (ed.). Eastern Christianity: a Crossroads of Cultures », Abstracta Iranica [En ligne], Volume 34-35-36 | 2017, document 4, mis en ligne le 15 juillet 2016, consulté le 28 septembre 2020. URL : http://journals.openedition.org/abstractairanica/41275 ; DOI : https://doi.org/ 10.4000/abstractairanica.41275

Ce document a été généré automatiquement le 28 septembre 2020.

Tous droits réservés 


\title{
Florence Jullien (ed.). Eastern Christianity: a Crossroads of Cultures
}

\author{
Christelle Jullien
}

\section{RÉFÉRENCE}

Florence Jullien (ed.). Eastern Christianity: a Crossroads of Cultures. Préface N. Garsoïan, Louvain, Peeters, 2012, xlvi-339 p. (Eastern Christian Studies 16)

1 Couvrant une période allant de l'Antiquité tardive à la fin du Moyen Âge, cet ouvrage réunit un choix de contributions d'auteurs qui ont marqué le champ des études chrétiennes orientales durant ces dernières décennies, en privilégiant une approche comparative originale - un aspect trop souvent négligé : à travers les rencontres et les échanges inter-culturels, il montre les assimilations et les appropriations, les mutations et l'émergence de nouvelles identités dans les aires géographiques où se sont développées les différentes expressions des christianismes en Orient. Ces interactions furent aussi des facteurs d'évolutions au sein des Églises particulières. Le christianisme d'expression syriaque se trouve en un certain sens à la croisée des relations entre les chrétiens d'Orient (arméniens, coptes, éthiopiens, géorgiens, grecs, perses). Une Préface du Professeur Nina Garsoïan ouvre ces études. Parmi les 9 articles sélectionnés, 8 ont été repris et réactualisés par leurs auteurs; la contribution de J. M. Fiey («Coptes et syriaques : contacts et échanges »), jusqu'ici peu accessible, a été revue par l'éditrice et complétée par celle de J. den Heijer. L'introduction de 45 pages offre un cadre conceptuel à cet ensemble et une réflexion particulièrement précise et utile sur la nature plurilingue, pluri-ethnique et multiculturelle du christianisme syriaque. Des rubriques subdivisent la thématique en cinq problématiques : I. Des traditions d'évangélisation partagées (Shared Traditions of Evangelisation), II. L'itinérance formative (Routes of Learning), III. Échanges et rencontres (Exchanges and Encounters), IV. Un bilinguisme comme milieu (Bilingualism as a Milieu), V. Élaboration de nouvelles identités (Shaping New Identities). Dans leur conjugaison, ces choix montrent comment 
les interférences entre chrétiens de ces espaces, et les exigences d'une acculturation, ont contribué à tisser des liens productifs et à faire apparaître des spécificités propres.

\section{AUTEURS}

\section{CHRISTELLE JULLIEN}

CNRS, Mondes iranien et indien, Paris 